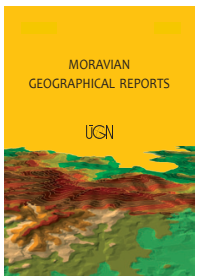

MORAVIAN GEOGRAPHICAL REPORTS

\title{
The geography of urban agriculture: New trends and challenges
}

\author{
Barbora DUŽI ${ }^{\text {a }}$, Bohumil FRANTÁL ${ }^{\text {a }}$, Marian SIMON ROJO ${ }^{\text {b }}$
}

\begin{abstract}
In the article, which is a theoretical and conceptual introduction for the Special Issue of Moravian Geographical Reports on 'New trends and challenges of urban agriculture in the context of Europe', the authors resume and review diverging issues of urban agriculture, exploring and discussing them from a geographical perspective and in a wider context of the transformation of urban and rural spaces, urban regeneration and renewal, agricultural restructuring, multifunctionality, ecosystem services, land-use conflicts and social responsibility. After the introduction that depicts a changing role of agriculture in the context of urban and rural transformations, the current research on urban agriculture in Europe is summarised and reviewed. Then the main trends and concepts of growing and expanding urban agriculture are presented and discussed with a special emphasis on the challenges these pose to geographers.
\end{abstract}

Keywords: urban agriculture, peri-urban agriculture, food production, urban farming, food gardening, Europe

Article history: Received 2 February 2017; Accepted 3 August 2017; Published 30 September 2017

\section{Introduction: Changing agriculture in the context of urban and rural transformations}

Several decades ago, the connection of words 'urban' and 'agriculture' sounded a little uncommonly and grandly within the geographical research, even though food production practices, at some extent, have been long present in and nearby cities. Only recently, particularly since the 1970s, this concept came out of the shadows and became a focus for many scientific disciplines, including geography (Smit and Nasr, 1992). The main ideas acknowledge the fact that cities are not only consumers of food and agricultural products, and the fact that food production does not belong only in the rural realm (Morgan, 2009). Still, one may ask why connect 'urban' and 'agriculture' if the current character of the food system has been considered as widely globalised, regarding the recent dramatic rise of the global trade in food and agricultural products (Busch and Bain, 2004; Wiskerke, 2016).

In general, 'farmers from somewhere' grow crops and hand over their products through the food processing, distribution and supply networks to stores, where urban customers finally buy it without any context-knowledge about the origin of their food. As described further in detail below, however, times have changed and recently the whole agro-food system has undergone unprecedented changes, shaping both urban and rural realms. Also, the goal of connecting 'urban' and 'food' together rises periodically, particularly in times of economic depression and related societal problems (Cohen and Garret, 2010; Partalidou and Anthopoulou, 2016). With regard to such matters, municipalities, urban planners, architects, researchers and individual actors involved in urban agriculture, are facing a great challenge in how to tackle these new phenomena.

Before focusing on the cities, some socio-demographic, economic and environmental processes in European rural spaces should be mentioned, especially those rural changes resulting in the realisation that as concerns food production, the rural landscape is no longer just the dominion of productive farming. In the early $2000 \mathrm{~s}$, the rural post-productivist transition had started to be discussed (Wilson, 2009; Almstead et al., 2014; Roche and Argent, 2015). Most authors agreed on the need to go beyond this "antipodean viewpoint" (cf. Roche and Argent, 2015) and rather preferred the better fitting concept of multifunctionality (Zasada, 2011; Wilson, 2009). This principle is also applied in the latest EU Common Agriculture Policy agenda, specifically through the placement at the core of its policy increasing sustainability and the joint provision of public and private goods (EC, 2013).

In summary, rural spaces have been experiencing a process of land use transformations, resting mainly in the decreasing proportion of agricultural land and processes of economic diversification. Thus, rural spaces are increasingly designed around alternative agricultural and various new industrial,

\footnotetext{
${ }^{a}$ Department of Environmental Geography, Institute of Geonics, The Czech Academy of Sciences, Brno, Czech Republic (*corresponding author: B. Duží; email: arobrab@centrum.cz)

${ }^{\mathrm{b}}$ Department of Urbanism and Regional Planning, Technical University of Madrid, Spain
} 
commercial, tourism and leisure activities, which have driven changes in rural identities and lifestyles (Frantál and Martinát, 2013; Frantál, Pasqualleti and Van der Horst, 2014; Martinát et al., 2016; Lange et al., 2013). Not surprisingly, these trends and challenges became the core subject of previous Special Issues of Moravian Geographical Reports (e.g. Frantál, Pasqualleti and van der Horst, 2014).

After three years, we turn our attention to urban spaces and their agricultural issues, to present a new Special Issue covering the role of agriculture in urban or peri-urban environments. It seems that interesting contexts and links between rural and urban transitions have just been revealed. While recent trends in European rural spaces show that their food production role is weakening, we may observe certain contradictory trends in urban spaces.

One crucial question is whether it is a matter of a "quantitative" or rather a "qualitative" dimension. In quantitative terms, some researchers have initialised research focusing on urban food production potential. They explore what kinds of foods, where, what methods and how much food can be grown in cities, and to what extent cities might become self-reliant in food production, taking into account their climatic, environmental and spatial constraints. This part of the story comprises the most popular research subjects, particularly in the US and Canada (Grewal and Grewal, 2012; Badami and Ramankutty, 2015; Napawan and Burke, 2016). On the contrary, Sovová (2015) provides a small-scale evaluation of production potential at the gardening level in Europe. Despite this contribution, we point out that the research potential of urban agriculture goes far beyond its narrowly-conceived food production dimension. We assume that rising concerns for urban agriculture and food issues in general, are part of wider societal changes, including perceptions of food issues.

First, food has been perceived not only as some amount to fill stomachs, but also the qualitative, health, environmental, social and other aspects of food are considered. Especially after the global wave of the nutrition transition based on the shift from traditional regional products to the nutrition poor processed fast food intake, we found that it brought a new kind of so-called malnutrition (a hidden hunger), resulting in increased obesity and the incidence of so-called civilisation diseases among inhabitants in many countries (Caballero, 2007).

Further, some parts of society started to be sensitive to sustainable, regional, aesthetic and cultural aspects of food origins, resulting in the so-called 'Slow Food Movement' and other kinds of public engagements in the food issues (Sassatelli and Davolio, 2010; Roe, Herlin and Speak, 2016). Eventually, the perception of the citizen's role has shifted from being just passive consumers to becoming active influencers or even participants in food issues and policy. In some regions, this has been manifested in the Food Sovereignty movement, which is defined as the "right of people to define their own food and agriculture" (Peoples Food Sovereignty Network, 2002; Patel, 2009; Sage, 2014).

Taking the preceding discussion into account, we suggest that many advanced research topics have surfaced for urban agriculture. Thus, the main aim of this Special Issue is to map the current state-of-the-art and to highlight selected important trends in urban agriculture research conducted to date in the context of Europe. Even though urban agriculture is undoubtedly a significant phenomenon in other countries of the Global North, particularly in the US and Canada, and it still plays an important role in developing countries across the world, it would be beyond the limits of this Issue to focus on other geographical regions. Hence, in this Issue we strive to investigate and discuss urban agriculture issues primarily from the perspective of geography or the spatial distribution and organisation of agro-food systems, particularly in the intraurban and peri-urban settings. We also take into account the role of the stakeholders involved, and especially the new kind and quality of relations between the producers and the consumers. We do not underestimate the role of the smallscale gardening dimension, as well.

\section{Urban agriculture research in Europe: Shaping the agenda}

Urban agriculture has been generally perceived as an engagement in food production or related activities within or nearby cities, practised by various stakeholders under different backgrounds, motivations and socio-economic conditions (Mougeot, 2006; FAO, 2007; Duží et al., 2014; Simon Rojo et al., 2015). It ranges from small scale food self-provisioning, generally known as urban gardening, which used to be practised by individuals or small group of gardeners, to a large scale urban farming being based on business principles.

To distinguish between diverse types of farms and gardens, several definitions and typologies have been introduced. They cover traditional gardens as well as new and unconventional forms, such as the community, educational, therapeutic, squatter or informal gardens/farms. One specific type comprises properly designed agricultural parks or agro-urban parks, focusing on maintaining and preserving agricultural land and activities at the urban fringes (Simon Rojo et al., 2015; Parham, 2015; Fanfani, 2013).

As a basic level, Simon-Rojo et al. (2015) purposefully distinguish three main types and set up urban food gardening as a small scale, mainly non-profit oriented gardening, conducted mainly between what they understand as urban farming and non-urban oriented farming. The first 'ideal' type takes advantage of the proximity to the city, building strong connections and offering local products and services to urban residents. ${ }^{1}$ The second one - a quite opposite type includes all the conventionally managed farms, which are located nearby cities, while their production and supply chain is oriented mainly on national or international markets. Empirical research shows, however, more diverse realities. Farms report a high diversity and complex patterns of farm production and output-related linkages, depending on different factors than just location near the city (Pangbourne and Roberts, 2015).

There is no doubt that the basic role of urban agriculture rests primarily on food production and the assurance of food security, together with its health and nutrition aspects. In this respect it has been conceptualised by the key institutions and researchers, such as the Food and Agricultural Organisation of the United Nations (FAO), World Health Organisation (WHO), Resource Centres on Urban Agriculture and Food Security (RUAF Foundation) and others (Mougeot, 2006;

\footnotetext{
${ }^{1}$ Closer look at the concept of peri-urban multifunctional farms has been at the website of Wageningen University, see: https:// www.wur.nl/en/newsarticle/Animation-on-strategies-for-Urban-agriculture-revenue-models-1.htm
} 
FAO, 2007; de Zeeuw and Dreshsel, 2015; de Zeeuw and Dubbeling, 2009; Gerster-Bertanya, 2013). Besides the mainly social and economic aspects of food production, urban agriculture has been recognised in a much broader, multifunctional context, encompassing the non-economic and other hardly quantifiable benefits (Hampwaye, 2013). Its environmental aspects and two-sided impacts are also widely discussed (Mok et al., 2014; Goldstein et al., 2016), as well as its potential contribution to the urban green and blue infrastructure (Timpe et al., 2015) and the improvement of urban food resilience (Cohen and Garret, 2010; de Zeeuw and Drechsel, 2015).

With regard to practical applications, urban agriculture implies a strong innovation dimension. Due to limited urban space and the restrained environmental conditions, food production inside cities has brought a lot of innovative agricultural approaches, starting from the application of soilless or the intensified plant growing technologies, to the identification of new places for production, such as vacant lots, roofs, walls, brownfields, idle or under-utilised land or even underground under artificial lighting (Smit and Nasr, 1992; Solon, 2014; Osborne, 2015; Opitz et al., 2016; Mok et al., 2014). Currently, the project 'Urban Green Train' is being realised with the support of the Erasmus+ Programme across Europe. Its main aim is to promote new urban agriculture business, particularly on a microand a meso-scale, through educational programs oriented to urban green innovations. When we focus on other research activities and action-oriented projects in Europe, we can mention several fruitful examples, including the FOODLINK, which deals with the sustainable urban food production and consumption, PLUREL that explored perurban land use and urban-rural relations or SUPURBFOOD, which focused on sustainable modes of urban and peri-urban food provisioning.

Recently, two $\mathrm{COST}^{2}$ Actions have explored the issue in depth. First, COST Action 'Urban Agriculture Europe' (TD1106, 2012-2016) covered several key issues of urban agriculture: dimensions and definitions, governance, entrepreneurial models, spatial visions and urban metabolisms. This scientific cooperation produced several valuable outputs, including the book 'Urban Agriculture Europe' (Lohrberg et al., 2015), or the Online Atlas of Urban Agriculture, drawing from newly created typology and covering selected case studies across Europe ${ }^{3}$. Moreover, several special issues dealing with urban agriculture are currently under preparation, including Moravian Geographical Reports (2017) and Nature and Culture (2018) journals ${ }^{4}$. Another COST Action 'Urban Allotment Gardens in European Cities' (TU1201, 20132017) focused mainly on the gardening level, particularly allotments. Besides exploring the social, environmental and other benefits of allotments, their incorporation into urban planning and urban fabric were also investigated. They valorised their research in the book 'Urban Allotment Gardens in Europe' (Bell et al., 2016).

The issue of urban agriculture has also penetrated to several conferences of geographers and sociologists where special sessions or panels were organised, such as, e.g. XXV ESRS Congress in Florence in 2013, covered sociological issues of rural resilience and vulnerability: the rural as locus of solidarity and conflict in times of crisis or IV EUGEO Congress in Rome in 2013, introducing actual geographical concepts. Since 2012, specific conferences focusing exactly on urban agriculture called "Agriculture in an Urbanizing Society" (AgUrb) take place every three years. The first edition of AgUrb was held in April 2012 in Wageningen, covering Multifunctional Agriculture and Urban-Rural Relations. The second (Rome, 2015) focused on Reconnecting Agriculture and Food Chains to Societal Needs. Next session is planned in Brazil (2018). Also, the Association of European Schools Of Planning (AESOP) takes into account the issue of urban food planning and its annual conferences (held since 2009) organised by the Sustainable Food Planning Group always includes urban and peri-urban agriculture issue.

It is not an exaggeration to claim that urban agriculture travels around the world, visibly in the form of the exhibition called 'Carrot City: Designing for Urban Agriculture'. The main idea of this exhibition was to disseminate ideas and knowledge about the best practices in urban agriculture by exploring the connection between urbanism, design and food. The exhibition was conceived by students and faculty at the Department of Architectural Science, Ryerson University in Canada and was first held in Toronto in 2009. Since then, the initiative has expanded, wrapped up new case studies, was presented across America, Europe, Africa and Asia and also a deserved book edition (Gorgolewski, Komisar and Nasr, 2011).

The issue of urban agriculture was important during the EXPO exhibition held in Milan in 2015, setting up the theme 'Feeding the Planet, Energy for Life'. After EXPO Milan Urban Food Policy Act - an international protocol so far signed by representatives of 152 cities from around the world who committed to developing food systems, based on principles of sustainability and social justice, including coordination of international food policies (MUFPA, 2016)

Food production and consumption in post-communist countries has also gained the special attention of social and geographical-oriented researchers due to its quite different geographical context, mainly the economic and sociopolitical developments during the second half of the $20^{\text {th }}$ century. On the key issues of their research focus, among others, became self-provisioning activities of gardeners, exploring their motivation and measuring the level of selfprovisioning. They also noticed social practices such as gifting, sharing and exchanging crop surpluses. Due to its specific character, widespread adoption and persistence over time or even various political regimes, they conceptualised this social practice as a 'quiet sustainability' (Smith and Jehlička, 2013; Smith, Kostelecký and Jehlička, 2016). Their main contribution rests on the extension of the food concept which has been applied mostly by West European researchers, who tended to understand urban food production rather as a food activism, promotion of social justice and environmental sustainability (de Hoop and Jehlička, 2017). Anyway, the quiet sustainability concept

\footnotetext{
${ }^{2}$ COST is abbreviation for European Cooperation in Science and Technology, for details see www.cost.eu

${ }^{3}$ For details see http://www.urbanagricultureeurope.la.rwth-aachen.de/online-atlas.html

${ }^{4}$ Urban Agriculture, feeding cities, food and landscapes also became the subjects of Special Issues in other Journals, such as International Planning Studies (2009), Journal of Agricultural Sustainability (2010) or Landscape Research (2016)
} 
has brought a deeper understanding of gardening, which has been widely practised for a very long time within the specific culture of former socialist Central and Eastern European countries.

Currently, challenging research questions are related to changing conditions for urban gardeners and farmers in post-communist countries in the light of their transition to market-based economies from the nineties to present. Contradictory factors, such as the impacts of globalisation on the one hand and the penetrating influence of alternative food ideas (for example alternative food networks, farm markets etc.) from the rest of Europe to a post-communist environment on the other hand, place this region into a unique position. The situation has been reflected from some points of view by Spilková and Perlín (2013), Spilková and Vágner (2016), Benedek and Balazs, (2016) or Gibas et al. (2013). One quite interesting application of not old fashioned, but still beneficial theories seems to be the geographical concept of 'travelling theory' (Said, 1983 in Fendrychová, 2015) applied by Fendrychová in research on the emergence and development of farmers' markets in Prague. According to Fendrychová (2015), several different concepts have been travelling from diverse 'western' contexts to the post-socialist countries and thus brought mutual interaction, as well as their clash with the specific local context.

\section{Current urban agriculture trends and concepts: A challenge for geographers}

Researchers from different academic backgrounds and specialisations have introduced some new terms and concepts to reflect new trends in urban agriculture (or the food issue in general), which started to permeate into multiple disciplines. Most of them reflect new, alternative, locally or regionally sustainable and environmentally sound models of food production, supply and consumption. Some concepts became quite trendy - dealing with the geographical proximity and establishing new forms of relationships among farmers and consumers who may partly share a responsibility for agricultural outputs or even straight forwardly contribute to food production, generally known as 'locavores'.

We can specifically mention local food systems (Holloway et al., 2007; Kirwan et al., 2013; Hiroki, Garnevska and McLaren, S., 2016; Kneafsey et al., 2015), short supply chains (Mundler and Laughrea, 2016), alternative food networks - AFNs (Renting, Marsden and Banks, 2003; Maye, 2013) and community supported agriculture - CSA (Hvitsand, 2016). These new approaches - roofed under the sustainable development concept - have been incorporated into urban municipal strategies in the form of urban food strategies and resilient urban food systems (Moragues et al., 2013; De Zeeuw and Dreschsel, 2015, Sonnino, 2016). Some European cities have already set up and started to implement urban food strategies, namely Milan, London, Malmö, Ghent or Vitoria. The participative approach is applied in the case of planning new agricultural parks in the peri-urban areas (Roth et al., 2015; IPR, 2015; Fanfani, 2013).

The geographical or spatial aspect (territoriality, urban peri-urban - rural space) plays an important role in mapping and conceptualising urban agriculture. The first question is, which perspective is more feasible to apply specifically in peri-urban spaces or simply the city fringes - urban-centric ones or perspectives from rural/ agricultural geography, considering the fact that these spaces are under development pressures and they experience conflicts between different land uses (Wästfelt and Zhang, 2016), or to overcome both of them and grasp them as a 'third space', drawing new synergies between the urban and rural processes and features (Fanfani, 2006 in Fanfani, 2013). A big challenge rests on the integration of peri-urban agriculture into spatial planning with respect to its potential for improving ecosystem services, cultural heritage, urban sustainable development and implementation of new, participatory forms of land use planning Simon Rojo et al., 2014; Grete Swensen and Jerpĺsen, 2008). In this respect, the concept of agricultural parks has been discussed, being developed and applied in several European peri-urban areas, including the first "swallows" in the Czech Republic (Fanfani, 2013; Roth et al., 2015; IPR, 2015).

The second challenge rests on exploring the meanings of the local or the regional and how they can be measured (Donald et al., 2010), together with the market-based context, i.e. the availability of potential suppliers or purchasers (Pangbourne and Roberts, 2015). In this sense, several methods and concepts have been introduced, the simplest one of which suggests food miles, measuring the distance from 'farm to plate' (Coley, Howard and Winter, 2009). A more complex concept of foodshed was developed and applied mainly in American cities. It represents the geographical area from which a population's food may be sourced, or it can cover more attributes, such as the agricultural methods used, the sustainability aspects, et cetera (Feagan, 2007).

Other new concepts have emerged to connect food production and landscapes, such as for example the Urban/ Local Foodscapes (Morgan and Sonnino, 2010; Sonnino, 2013; Roe, Herlin and Speak, 2016), the Continuous Productive Urban Landscape (CPUL), a concept introduced and developed by Viljoen and Bohm (2014) or the Edible (Urban) Landscapes, Foodspace (Parham, 2015) or even the Edible City (de la Salle and Holland, 2010 in Cohen, 2011).

Associated with the question of environmental and food justice, we should mention the contradictory concept of food deserts that points out the dark side of ineffective food production and planning and can feasibly show to demonstrate geographical representation. Food deserts are generally defined as parts of the country/city with the lack access to fresh fruit, vegetables, and other healthful whole foods (Whelan et al., 2002).

Many authors who incorporate productive landscapes into cities and understand them as an essential element of sustainable urban infrastructure, contributed to the development of new idea recently applied in urban planning - food urbanism. Besides that, calls for a new theoretical synthesis in urban food studies aiming to reconnect food, health, nature and politics of the urban food movement are emerging (Morgan, 2015). In this way, some geographers tried to summarise and conceptualise this new field of research at least partially as an alternative food geography (Wiskerke, 2009) or new geography of food security (Sonnino, 2016).

Finally, we have to mention some quite underestimated and adverse aspects of urban agriculture hidden in the enthusiastic wave of urban agriculture. First, the cities in their current forms are still not so favourable and clean places to live. More specifically, they suffer from a certain level of air pollution and soil contamination from previous 
as well as current activities. These concerns stem from the fact that urban or peri-urban soils may be contaminated to some extent, particularly the vacant soils or lands located near industrial sites or near roadways loaded with heavy traffic, also organic waste as a potential source for compost might then contain some traces of health and environmental risk substances (Nehls et al, 2015; Säumel et al., 2012; Schwarz et al., 2016). Second, urban agriculture may also contribute to the improvement of but also to the deterioration of urban environments, and it contributes to the increase of carbon footprint if not planned and practised wisely and in an environmentally friendly way (Mok et al., 2014; Duží et al., 2014). We point out that even though there is a strong motivation to produce the local food, we should not underestimate some environmental and health circumstances connected with specific urban or peri-urban conditions.

To sum up, the current linking stream is unexceptionable: starting from individual, fragmented activities, urban agriculture has been already included in city or regional planning, coherent strategies connecting sustainable development, local food systems and new forms of municipal or regional development strategies. Understanding that agriculture and food production are shifting from an anonymous production and becoming more familiar, while people want to know who their farmer is and where the food comes from. Myriad of grass-root initiatives, civil and education platforms, institutions, researchers and city councils envisioning a future of re-localisation of food production and reconnection of urban dwellers with the experience of growing vegetables and adopting healthier diets with fresh food. Daily, we can read news about how some municipalities started to promote local or organic food consumption in public institutions like schools, hospitals or offices, or actively support the complex way of local food production and consumption.

For us, the researchers, it is surely an exciting research agenda. It is worth exploring urban agriculture, to write about it or put it into practice, isn't it? For geographical research, the most attractive aspect is its spatial organisation, i.e. the location and spatial distribution of agricultural activities within the urban space, its durability and feasibility, the real or potential clashes over land use and the overall question dealing with the level and extent of re-localisation of the food system - whether to count with some form of administrative, physical boundaries or placeless - abstract scale. Another aspect for consideration is to what extent is feasible and sustainable to become local? How can geographers contribute to the mapping of this phenomenon? How can the food issue be implemented into urban planning?

Thus, geography and especially the geographers of food received "fresh food", and a new impulse for conducting fruitful geographical research. On the other hand, despite its current huge wave of enthusiasm, there is a strong need to apply a sober-minded research approach. Some authors pointed out that the local production should not be realised at any cost and that the climatic, environmental and other consequences should be taken into account seriously (Mok et al., 2014; Goldstein et al., 2016). The crucial questions then are "Under which climatic and other conditions and on what scale can the urban agriculture be realised?" and "What kind of impacts and unintended consequences might result from its spatial expansion?"

\section{Special issue of MGR on "New trends and challenges of urban agriculture in the context of Europe"}

The papers collected in this volume address many of the core issues in the urban space (landscape) - agriculture nexus, from questions about what the urban agriculture is for, and who has what stake in particular patterns of economic developments related to agriculture, to measures of efficiency, problems of scalability, place making, justice and right to the urban space, and questions of producersconsumers interactions and knowledge production.

In the first paper, Cecília Delgado suggests that urban agriculture social economy enterprises and the utilisation of vacant urban land can be a driving force of the post-crisis urban agriculture sustainable development in European cities, if being supported by proper public policies. The provided indepth analysis of a sample of Portuguese urban agriculture initiatives revealed that the effective urban agriculture initiatives are led by young entrepreneurs, making a positive use of social networks, being committed to social and economic values, which expanded successfully generating jobs in the time of the crisis. The Portuguese development can be an example for other European cities as well.

The spatial dimension of urban agriculture from the perspective of the cultural meaning of lived experience, the value of place (and the place attachment) and emerging social conflicts over the future of urban allotment gardens (considered as a symptom of broader power dynamics and the public right to space) are grateful research subjects not only for sociologists and ethnographers but also for human geographers. In the second paper, Marlinde Koopmans, Daniel Keech, Lucie Sovová and Matt Reed try to bring these two topics together, viewing them as two co-constitutive forces that shape the places of urban agriculture. They analyse three case studies in different European cities (Bristol, Brno and Ghent), using a spatial lens that exposes important tensions as inherent characteristics of urban agriculture and they conceptualise them as tensions within two space-narratives, namely abstract space and concrete place.

Existing research studies have shown that the complexity of urban agriculture is hardly compressible into classic business management models. In the third paper, Bernd Pölling, Maria-José Prados, Bianca Maria Torquati, Giulia Giacchè, Xavier Recasens, Chiara Paffarini, Oscar Alfranca and Wolf Lorleberg propose a new management model called Business Model Canvas (BMC) which should be more useful for understanding the complexities of urban agriculture development. Based on a comparative analysis of case studies from Spain, Italy and Germany, they point out how farm enterprises have to adjust to different urban conditions by stepping into appropriate business models aiming to stay competitive and profitable and how the Canvas business model can be useful to analyse their organisation and performance, both economically and socially.

Consumer-producer interactions and collaboration have been considered a characteristic feature of so called alternative food networks. More general concepts for describing these interactions are, however, lacking. In the fourth paper, Ina Opitz, Kathrin Specht, Annette Piorr, Rosemarie Siebert and Ingo Zasada propose an analytical framework relying on six domains of consumer-producer interactions, which are then applied for investigating the effects of interactions on consumers' learning about agriculture and rurality. Based 
on the findings from guided interviews with consumers and producers of selected alternative food networks in Germany they suggest that the participation in alternative food networks enhances consumers' learning about food and agricultural production, where specific food networks are characterised by specific learning channels and contents.

It has been widely acknowledged in the literature that the classical urban-rural dichotomy is no longer valid taking into account the ongoing suburbanisation, urban sprawl and related phenomena. The urban development has generated a range of peri-urban transitional areas in which urban and rural land uses are mixed in a fragmented land mosaic. Based on a comparative analysis of the long-term evolution and land use changes in the Southern Madrid and Oviedo metropolitan areas, Nerea Morán Alonso, Ícaro Obeso Muniz, Agustín Hernández Aja and Felipe Fernández García in the fifth paper attempt to detect opportunities and provide policy implications for the revitalisation of periurban agriculture.

In the last paper, Attila Tóth and Axel Timpe would like to contribute to the existing geographical research by new inspiration in the form of application of figure-ground plans or figure-ground analysis, which is a widely used analytical tool in the landscape architecture and landscape planning. Using the Urban Atlas as a data source, the authors present and discuss the application of figureground plans in combination with complex land-use maps for spatial analysis of urban agriculture as a component of multifunctional urban green infrastructures in selected European cities. The presented results demonstrate the scale and diversity of metropolitan regions and different spatial patterns of urban agriculture at the regional level and in central urban areas.

It seems the presented studies well represent a combination of the scientific view of academic researchers on the subject, trying to find out spatial and economic patterns and theoretically conceptualise the problems of urban agriculture developments, with a rather practical view on daily interactions between actors and stakeholders of urban agriculture providing potential readers with important implications for spatial planning and local governance.

\section{Acknowledgement}

The paper was elaborated in the scope of the project "Integrated Spatial Planning, Land Use and Soil Management Research Action (INSPIRATION) (Grant No. 681256, Horizon 2020) funded by the European Commission in order to develop a Strategic Research Agenda (SRA) for Europe on soil, land use and land management.

\section{References}

ALMSTEAD, A., BROUDER, P., KARLSSON, S., LUNDMARK, L. (2014): Beyond post-productivism: from rural policy discourse to rural diversity. European Countryside, 4: 297-306.

BADAMI, M. G., RAMAKUTTY, N. (2015): Urban agriculture and food security: a critique based on an assessment of urban land constraints. Global Food Security, 4: 8-15.

BENEDEK, Z., BALAZS, B. (2016): Current status and future prospect of local food production in Hungary: a spatial analysis. European Planning Studies, 24(3): 607-624.
BELL, S., FOX-KÄMPER, R., KESHAVARZ, N., BENSON, M., CAPUTO, S., NOORI, S., VOIGT, A. [eds.] (2016): Urban allotment gardens in Europe. Earthscan.

BOHM, K., VILJOEN, A. (2014): The Edible City: Envisioning the Continuous Productive Urban Landscape (CPUL). Field: a free journal for the architecture. 4(1): 149-151.

BUSCH, L., BAIN, C. (2004): New! Improved? The Transformation of the Global Agrifood System. Rural Sociology, 69(3): 321-346.

CABALLERO, B. (2007): The Global Epidemic of Obesity: An Overview. Epidemiologic Reviews, 29: 1-5.

COHEN, M. J., GARRETT, J. L. (2010): The food price crisis and urban food (in)security. Environment and Urbanisation. 22(2): 467-482.

COHEN, N. (2011): Book Review: Agricultural Urbanism: Handbook for Building Sustainable Food Systems in $21^{\text {st }}$ Century Cities, edited by Janine de la Salle and Mark Holland. Journal of Agriculture, Food Systems, and Community Development. 2(1): 319-321.

COLEY, D. A., HOWARD, M., WINTER, M. (2009): Local food, food miles and carbon emissions: A comparison of farm shop and mass distribution approaches. Food Policy, 34(2): 150-155.

DE HOOP, E., JEHLIČKA, P. (2017): Reluctant pioneers in the European periphery? Environmental activism, food consumption and "growing your own". Local Environment, Available at: http://dx.doi.org/10.1080/135 49839.2017.1289160

DE ZEEUW, H., DRESCHSEL, P. [eds.] (2015): Cities and agriculture. Developing resilient urban food systems. New York, Routledge.

DE ZEEUW, H., DUBBELING, M. (2009): Cities, food and agriculture: challenges and the way forward. Leusden, RUAF Foundation.

DONALD, B., GERLTER, M., GRAY, M., LOBAO, L. (2010): Re-regionalizing the food production. Cambridge Journal of Regions, Economy and Society, 2(3): 171-175.

DUŽÍ, B., TÓTH, A., BIHUŇOVÁ, M., STOJANOV, R. (2014): Challenges of urban agriculture. Highlights on Czech and Slovak experience. In: Vávra, J., Lapka, M., Cudlínová, E. [eds.]: Current Challenges of Central Europe: Society and Environment (pp. 82-107). Prague, Charles University.

EUROPEAN COMMISSION (2013): Overview of the CAP reform 2014-2020. Agriculture Policy Perspective Brief, 5: 1-10.

FANFANI, D. (2006): Il governo del territorio e del paesagio rurale nello spazio "terzo" periurbano. Il parco agricolo come strumento di politiche e di progetto", in Ri-Vista Ricerche per la progettazione del paessagio, Semestrale on line del Dotorato di Ricerca in progettazione paesística, DUPT, Facolta di Architettura di Firenze, N. 6 Lugio-Dicembre 2006.

FANFANI, D. (2013): "Local Development and "AgriUrban" Domain: Agricultural Park as Promotion of an "Active Ruralship". Planum. The Journal of Urbanism, 27(2): 38-47.

FENDRYCHOVÁ, L. (2015): The 'other' geography of alternative food networks: farmers' markets as a travelling concept. Dissertation thesis. Praha, Univerzita Karlova, Př́rodovědecká fakulta. 
FAO (2007): Profitability and Sustainability of Urban and Peri-urban Agriculture. Rome, FAO.

FEAGAN, R. (2007): The place of food: mapping out the 'local' in local food systems. Progress in Human Geography, 31(1): 23-42.

FRANTÁL, B., MARTINÁT, S. (2013): New challenges, conflicts and opportunities for rural spaces. In: Frantál, B., Martinát, S. [eds.]: New rural spaces: towards renewable energies, multifunctional farming and sustainable tourism (pp. 6-16). Brno, UGN.

FRANTÁL, B., PASQUALLETI, M., VAN DER HORST, D. (2014): New trends and challenges for energy geographies. Moravian Geographical Reports, 22(2): 2-6.

GERSTER-BENTAYA, M. (2013): Nutrition-Sensitive Urban Agriculture. Food Security, 5: 723-737.

GOLDSTEIN, B., HAUSCHILD, M., FERNÁNDEZ, J., BIRKVED, M. (2016): Testing the environmental performance of urban agriculture as a food supply in northern climates. Journal of Cleaner Production. 135: 984-994.

GORGOLEWSKI, M., KOMISAR, J., NASR, J. (2011): Carrot City: Creating Places for Urban Agriculture. Monacelli Press.

GIBAS, P., MATĚJOVSKÁ, L., NOVÁK, A., ROLFOVÁ, E., TVARDKOVÁ, E., VALEŠOVÁ, I., VESELÝ, M. (2013): Zahrádkové osady: Stíny minulosti nebo záblesky budoucnosti? Praha: Charles University.

HAMPWAYE, G. (2013): Benefits of urban agriculture: Reality of illusion? Geoforum, 49: R7-R8.

HIROKI，S., GARNEVSKA， E., MCLAREN, S. (2016): Consumer Perceptions About Local Food in New Zealand, and the Role of Life Cycle-Based Environmental Sustainability. Journal of Agricultural and Environmental Ethics, 29(3): 479-505.

HOLLOWAY, L., KNEAFSEY, M., VENN, L., COX, R. DOWLER, E., TUOMAINEN, H. (2007): Possible Food Economies: a Methodological Framework for Exploring Food production-Consumption Relationships. Sociologia Ruralis, 47(1): 1-19.

HVITSAND, C. (2016): Community supported agriculture (CSA) as a transformational act-distinct values and multiple motivations among farmers and consumers. Agroecology and Sustainable food systems, 40(4): 333-351.

IPR (2015): Cooperative planning for periurban park at Vltava and Berounka River. [cit. 01.03.2017]. Available at: http://en.iprpraha/clanek/1409/cooperative-planningfor-periurban-park-at-vltava -and-berounka-river

KIRWAN, J., ILBERY, B., NAYE, D., CAREY, J. (2013): Grassroots social innovations and food localization: An investigation of the Local Food programme in England. Global Environmental Change, 23(5): 830-837.

KNEAFSEY, M., VENN, L., SCHMUTZ, U., BALÁZS, B., TRENCHARD, L., EYDEN-WOOD, T., BLACKETT, M. (2013): Short food supply chains and local food systems in the EU. A state of play of their socio-economic characteristics. JRC Scientific and Policy Reports. Joint Research Centre Institute for Prospective Technological Studies, European Commission.
LANGE, A., PIORR, A., SIEBERT, R., ZASADA, I. (2013): Spatial differentiation of farm diversification: How rural attractiveness and vicinity to cities determine farm households' response to the CAP. Land Use Policy, 31: 136-144.

LOHRBERG, F., LICKA, L., SCAZZOSI, L., TIMPE, A. [eds.] (2015): Urban Agriculture Europe. Berlin, Jovis Verlag.

MARTINÁT, S., NAVRÁTIL, J., DVOŘÁK, P., VAN DER HORST, D., KLUSÁČEK, P., KUNC, J., FRANTÁL, B. (2016): Where AD plants wildly grow: The spatiotemporal diffusion of agricultural bio gas production in the Czech Republic. Renewable Energy, 95: 85-97.

MAYE, D. (2013): Moving Alternative Food Networks beyond the Niche. International Journal of Sociology of Agriculture and Food. 20(3): 383-389.

MORAGUES, A., MORGAN, K., MOSCHITZ, H., NEIMANE, I., NILSSON, H., PINTO, M., ROHRACHER, H., RUIZ, R., THUSWALD, M., TISENKOPFS, T., HALLIDAY, J. (2013): Urban Food Strategies: the rough guide to sustainable food systems. Document developed in the framework of the FP7 project FOODLINKS.

MOK, H. F., WILLIAMSON, V. G., GROVE, J. R., BURRY, K., BARKER, F., HAMILTON, A. J. (2014): Strawberry fields forever? Urban agriculture in developed countries: a review, Agrononomy for Sustainable Development, 34: 21-43.

MORGAN, K. (2009) Editorial: Feeding the City. The Challenge of Urban Food Planning. International Planning Studies 14(4): 341-348.

MORGAN, K. (2015): Nourishing the city. The rise of the urban food question in the Global North. Urban Studies, 52(8): 1379-1394.

MORGAN, K., SONNINO, R. (2010): The urban foodscape: world cities and the new food equation, Cambridge Journal of Regions, Economy and Society 3(2): 209-224.

MOUGEOT , L. J. A. (2006): Growing better cities: urban agriculture for sustainable development. Ottawa, International Development Research Centre.

MUFPA (2015): Milan Urban Food Policy Pact. [cit. 05.09.2016]. Available at: http://www. milanurbanfoodpolicypact.org/

MUNDLER, P., LAUGHREA, S. (2016): The contribution of short supply chains to territorial development: A study of three Quebec territories. Journal of Rural Studies, 45: 218-229.

NAPAWAN, N. C., BURKE, E. (2016): Productive potential: evaluating residential urban agriculture. Landscape Research, 41(7): 773-779.

NEHLS, T., JIANG, Y., DENNEHY, C, ZHAN, X., BEESLEY, L. (2015): From waste to value: urban agriculture enables cycling of resources in cities. In: Lohrberg, F., Lička, L., Scazzosi, L., Timpe, A. [eds.]: Urban Agriculture Europe, (pp. 170-173). Berlin, Jovis.

OPITZ, I., SPECHT, K., BERGERS, R., SIEBERT, R., PIORR, A. (2016): Toward Sustainability: Novelties, Areas of Learning and Innovation in Urban Agriculture. Sustainability, 8: 1-18. 
OSBORNE, M. (2015): Urban farming's growing importance. TechBerlin, $1^{\text {st }}$ June. [cit. 11.01.2017]. Available at: https://techberlin.com/articles/urban-farmings-growingimportance/

PANGBOURNE, K., ROBERTS, D. (2015): Small Towns and Agriculture: Understanding the Spatial Pattern of Farm Linkages. European Planning Studies, 23(3): 494-508

PARPALIDOU, M., ANTHOPOULOU, T. (2016): Urban Allotment Gardens During Precarious Times: From Motives to Lived Experiences. Sociologia Ruralis, DOI: 10.1111 /soru. 12117

PARHAM, S. (2015): The productive periphery: food and urbanism on the edge. In: Cina, G., Dansero, E. [eds.]: Localizing urban food strategies. Farming cities and performing rurality. $7^{\text {th }}$ International AESOP Sustainable Food Planning Conference Proceedings, 7-9 October 2015 (pp.118-130), Torino.

PATEL, R. (2009): What does food sovereignty like? Journal of Peasant Studies, 36(3): 663-706.

PEOPLES FOOD SOVEREIGNTY NETWORK (2007) Statement on peoples' food sovereignty. $11 \mathrm{pp}$. [cit. 01.08.2017]. Available at: http://www2.worldgovernance.org/article70.html

RENTING, H., MARSEDEN, T. K., BANKS, J. (2003): Understanding alternative food networks: exploring the role of short food supply chains in rural development. Environment and Planning A, 35: 393-411.

ROCHE, M., ARGENT, N. (2012): The fall and rise of agricultural productivism? An Antipodean viewpoint. Progress in Human Geography, 39(5): 621-635.

ROE, M., HERLIN, I. S., SPEAK, S. (2016): Identity, food and landscape character of urban context. Landscape Research, 41(7): 757-772.

ROTH, M., FRIXEN, M., TOBISCH, C., SCHOLLE, T. (2015): Finding Spaces for Urban Food Production Matching Spatial and Stakeholder Analysis with Urban Agriculture. Approaches in the Urban Renewal Area of Dortmund-Hörde, Germany. Journal on Food, Agriculture and Society 3(1): 79-88.

SAGE, C. (2014): The transition movement and food sovereignty: From local resilience to global engagement in food system transformation. Journal of Consumer Culture, 14: 254-275.

SASSATELLI, R., DAVOLIO, F. (2010): Consumption, Pleasure and Politics Slow Food and the politico-aesthetic problematization of food. Journal of Consumer Culture, 10(2): 202-232.

SÄUMEL, I., KOTSYUK, I., HÖLSCHER, M., LENKEREIT, C., WEBER, F., KOWARIK, I. (2012): How healthy is urban horticulture in high traffic areas? Trace metal concentrations in vegetable crops from plantings within inner city neighbourhoods in Berlin, Germany. Environmental Pollution, 165: 124-132.

SIMON ROJO, M., MORATALLA, A. Z., ALONSO, N. M., JIMENEZ, V. H. (2014): Pathways towards the integration of peri-urban agrarian ecosystems into the spatial planning system. Ecological Processes, 3(13): 16.

SIMON-ROJO, M., RECASENS, X., CALLAU, C., DUŽÍ, B., EITER, S., HERNANDEZ-JIMENEZ., V., LAVISCIO, R.,
LOHRBERG, F., PICKARD, D., SCAZZOSI, L., VEJRE, H. (2015): From urban Food Gardening to Urban Farming. In: Lohrberg, F., Scazzosi, L., Lička, L. Timpe, A. [eds.]: Urban Agriculture Europe (pp. 24-31). Berlin: Jovis.

SCHWARZ, K., CUTTS, B. B., LONDON, J. K., CADENASSO, M. L. (2016): Growing gardens in shrinking cities: A Solution to the Soil Lead Problem? Sustainability, 8(2): 1-11.

SMIT, J., NASR, J. (1992): Urban agriculture for sustainable cities: using wastes and idle land and water bodies as resources. Environment and Urbanisation, 4(2): 141-152.

SMITH, J., JEHLIČKA, P. (2013): Quiet sustainability: Fertile lessons from Europe's productive gardeners (2013). Journal of Rural Studies, 32: 148-157.

SMITH, J., KOSTELECKÝ, T., JEHLIČKA, P. (2015): Quietly does it: questioning assumptions about class, sustainability and consumption. Geoforum, 67: 223-232.

SOLON, O. L (2014): Vast underground bomb shelter reappropriated by urban farmers. Wired, $11^{\text {st }}$ February. [cit. 11.01.2017]. Available at: http://www.wired.co.uk/ article/underground-farm-zero-carbon-food

SONNINO, R. (2013): Local foodscapes: place and power in the agri-food system. Acta Agriculturae Scandinavica, Section B - Soil \& Plant Science, 63(Supplement 1): 2-7.

SONNINO, R. (2016): The new geography of food security: exploring the potential of urban food strategies. The Geographical Journal, 182(2): 190-200.

SOVOVÁ, L. (2015): Self-provisioning, sustainability and environmental consciousness in Brno allotment gardens. Sociální studia, 12(3): 11-26.

SPILKOVÁ, J., VÁGNER, J. (2016): The loss of land devoted to allotment gardening: The context of the contrasting pressures of urban planning, public and private interests in Prague, Czechia. Land Use Policy, 52(March): 232-239.

SPILKOVÁ, J., PERLÍN, R. (2013): Farmers' markets in Czechia: risks and possibilities. Journal of Rural Studies 32(10): 220-229.

SWENSEN, G., JERPÃSEN, G. P. (2008): Cultural heritage in suburban landscape planning. A case study in Southern Norway. Landscape and Urban Planning, 87: 289-300.

TIMPE, A., CIESZEWSKA, A., TÓTH, A. (2015): Urban Agriculture Goes Green Infrastructure. In: Lohrberg, F., Scazzosi, L., Lička, L., Timpe, A. [eds.]: Urban Agriculture Europe (pp. 126-131). Berlin: Jovis.

URBAN GREEN TRAIN (2016): [cit. 11.01.2017]. Available at: http://www.urbangreentrain.eu/

WÄSTFELT, A., ZHANG, Q. (2016): Reclaiming localization and revitalising agriculture: A case study of peri-urban agricultural change in Gotheburg, Sweden. Journal of Rural Studies, 47: 172-185.

WHELAN, A., WRIGLEY, N., WARM, N., CANNING, S. E. (2002): Life in a 'Food Desert'. Urban Studies, 39(11): 2083-2100. 
WILSON, G. A. (2009): Post-Productivist and multifunctional agriculture. International Encyclopedia of Human Geography, p. 379-386.

WISKERKE, J. S. C. (2009): On places lost and places regained: Reflections on the alternative food geography and sustainable regional development. International planning studies, 14(4): 369-387.
WISKERKE, J. S. C. (2016): Urban food systems. In: De Zeeuw, H, Drechsel, P. [eds.]: Cities and Agriculture. Developing resilient urban food systems (pp. 1-26). New York, Routledge.

ZASADA, I. (2011): Multifunctional peri-urban agriculture-A review of societal demands and the provision of goods and services by farming. Land Use Policy, 28(4): 639-648.

\section{Please cite this article as:}

DUŽÍ, B., FRANTÁL, B., SIMON ROJO, M. (2017): The geography of urban agriculture: New trends and challenges. Moravian Geographical Reports, 25(3): 130-138. Doi: 10.1515/mgr-2017-0012. 